\title{
COMPARISON OF GOOD CORPORATE GOVERNANCE DISCLOSURE AND ACHIEVEMENT OF THE MAQASHID SHARIAH BETWEEN INDONESIAN AND MALAYSIAN ISLAMIC BANKS
}

\author{
Ima Maspupah ${ }^{1^{*}}$ and Shofia Mauizotun Hasanah ${ }^{2}$ \\ ${ }^{1}$ Universitas Siliwangi, Tasikmalaya, Indonesia \\ ${ }^{2}$ Institut Agama Islam Hamzanwadi NW, Pancor, Indonesia
}

\begin{abstract}
As part of the corporate organization, Islamic banks are encouraged to create good performance. But in the benchmark, there are still Islamic banks that assess the performance of banks using conventional measuring instruments. So in this study using maqashid index approach to measure the performance of Islamic banks. In addition to creating good performance, the obligations of business organizations are also to take part in activities aimed at protecting and improving the welfare of society as a whole and creating good corporate governance. banks in Indonesia have poor corporate governance rankings compared to neighboring countries such as Malaysia. So the purpose of this comparison study, it is hoped that there will be some advantages between them that can be identified. The method used in this research is quantitative method by using Mann-Whitney test. The data used are annual reports from three Indonesian islamic banks and three Malaysian Islamic banks. The results obtained no significant differences in Good Corporate Governance between Indonesian and Malaysian Islamic banks. While the achievement of maqashid shariah both have differences. This is because, firstly, the difference between banking history and the second, the difference of implementation of Shariah compliance in both countries.
\end{abstract}

Keywords: Good Corporate Governance, Islamic Banking, Maqashid Shariah

\section{INTRODUCTION}

Islamic banks are financial institutions that perform the function of financial intermediation primarily aimed at the wider community for financial transactions selected in accordance with Islamic principles. In its implementation, this Islamic Shari'a-based banking system has expanded widely in various countries including in western countries. Syariah banks are growing very rapidly around the world. According to Eagle, the number of Sharia banks in the world in 2010 is 300 banks with total assets worth US \$ 700 billion in 70 countries in the world such as Indonesia, Malaysia, Saudi Arabia and United Kingdom. ${ }^{1}$ Particularly in Indonesia, Otoritas Jasa Keuangan (OJK) recorded as of June 2016, the sharia banking sector has total assets of Rp306.23 trillion consisting of 12 Sharia (Islamic) Branches, 22 Sharia Business Units (Sharia Divisions) and 165 Shariah Financing Banks (BPRS). ${ }^{2}$

Islamic banks, seen from the asset side has grown quite rapidly with an estimated growth of $17.6 \%$ increase over the last 4 years with the ability to

* Corresponding author. Email address: maspupahima@gmail.com

1 Eagle, L, Exporting Islamic Banking From the Middle East, (. London: Banker's Academy Briefings, 2010). p.55.

${ }^{2}$ www.ekbis.sindonews.com accessed November 13, 2016. 
generate profits of $12.6 \%$. The performance is predicted to increase along with the interest of the community towards sharia bank. ${ }^{3}$ This increase should also be accompanied by improvements in the welfare of internal and external parties that can be seen in corporate governance or good corporate governance.

Without effective corporate governance implementation, sharia banks will be difficult to strengthen their position, expand their networks, and demonstrate their performance more effectively. The need for sharia banks for corporate governance is becoming more serious as the complexity of the problems faced, which will undermine the bank's ability to face long-term challenges. Thus, it is imperative for sharia banks to use a measure that can help improve their role through good corporate Islamic business. ${ }^{4}$

In 2014, the Asian Corporate Governance Association (ACGA) reported the results of the study on the implementation of GCG in Asia, showing that Indonesia is at the bottom or worst in Asia with a score of $39 \%$ far below Malaysia which has a score of 58\%. From 2010, Indonesia still remains at the bottom of Asia, as shown in the table below. ${ }^{5}$

Table 1 Market Ranking and Scores, 2014

\begin{tabular}{|c|c|c|c|c|c|}
\hline \multicolumn{6}{|c|}{ Corporate Governance Watch Market scores: 2010 to 2014} \\
\hline & 2010 & 2012 & 2014 & $\begin{array}{c}\text { Change 2012 vs } \\
2014\end{array}$ & Trend of CG reform \\
\hline Hongkong & 65 & 66 & 65 & $(-1)$ & $\begin{array}{l}\text { Weak leadership, tough } \\
\text { enforcement }\end{array}$ \\
\hline Singapore & 67 & 69 & 64 & $(-5)$ & International vs local \\
\hline Japan & 57 & 55 & 60 & $(+5)$ & $\begin{array}{l}\text { Landmark changes, can } \\
\text { they be sustined? }\end{array}$ \\
\hline Thailand & 55 & 58 & 58 & - & $\begin{array}{l}\text { Improving, but new } \\
\text { legislation needed }\end{array}$ \\
\hline Malaysia & 52 & 55 & 58 & $(+3)$ & $\begin{array}{l}\text { Improving, but still too } \\
\text { top-down }\end{array}$ \\
\hline Taiwan & 55 & 53 & 56 & $(+3)$ & $\begin{array}{l}\text { Bold policy moves, can } \\
\text { they be sustained? }\end{array}$ \\
\hline India & 48 & 51 & 54 & $(+3)$ & $\begin{array}{l}\text { Bouncing back, Delhi } \\
\text { more supportive }\end{array}$ \\
\hline Korea & 45 & 49 & 49 & - & $\begin{array}{l}\text { Indifferent leader, more } \\
\text { active regualtion }\end{array}$ \\
\hline China & 49 & 45 & 45 & - & $\begin{array}{l}\text { Focus on SOE reform, } \\
\text { enforcement }\end{array}$ \\
\hline Philippines & 37 & 41 & 40 & $(-1)$ & $\begin{array}{l}\text { Show reform, improved } \\
\text { company reporting }\end{array}$ \\
\hline Indonesia & 40 & 37 & 39 & $(+2)$ & $\begin{array}{l}\text { Big ambitions, can they } \\
\text { be achieved? }\end{array}$ \\
\hline
\end{tabular}

Source: Asia Corporate Governance Association (ACGA), 2014.

Based on the data in the above table it shows that weak legislation in the country of Indonesia governing business activities and coupled with law enforcement is very weak compared with other Asian countries. Based on this, the disclosure of Good Corporate Governance needs to be discussed in this

\footnotetext{
${ }^{3}$ World Islamic Banking Competitiveness Report 2013-2014, p.08.

${ }^{4}$ Umer Chapra dan Habib Ahmed, (2008). Corporate Governance Lembaga Keuangan Syariah, Jakarta: Bumi Aksara, p.13.

${ }^{5}$ www.ACGA-Asia.org accessed October 21, 2016 At 18:47.
} 


\section{COMPARISON OF GOOD CORPORATE GOVERNANCE DISCLOSURE AND ACHIEVEMENT OF THE MAQASHID SHARIAH BETWEEN INDONESIAN AND MALAYSIAN ISLAMIC BANKS}

study by selecting the most acclaimed syariah bank object in corporate governance reporting.

In the management of sharia banks should meet the objectives of sharia (maqasid shariah). Furthermore, Mannan states that Sharia banks must contribute to the improvement of the welfare of the community (ummah) and are not allowed to operate if only to obtain maximum profit. ${ }^{6}$ Achieving the goal of the Islamic banks itself is maqashid shariah. To be able to achieve the Maqashid Shariah, a Shariah business institution must be able to take care of alaql (mind), addien (religion), nafs (soul), nasl (descent), and maal (treasure). In the context of Sharia business practices, the achievement of Maqashid Shariah can be measured through the achievement of the goals of individual education, the creation of fairness and the achievement of the public interest.

Malaysia and Indonesia are two Muslim countries in Southeast Asia, which, when examined, have many similarities. Both countries are dominated by the Malay population, many follow the Shafi'i madhhab as well as the existence of strong adat influence in the legal system. ${ }^{7}$ Malaysia is the first country to introduce sharia banking system in Southeast Asia. In harmony with its rapid development and planning the various plans and efforts that have been implemented. It is evident that Malaysia is still listed as the country with the largest sharia financial assets in Southeast Asia and in the world. The value in December 2014 even reached US $\$ 423.2$ billion. ${ }^{8}$ With the second rank in the world in 2015. More details can be seen in the table below:

Table 2 IFCI Rangking 2014 \& 2015

\begin{tabular}{|c|c|c|c|c|c|}
\hline \multicolumn{2}{|c|}{ COUNTRIES } & $\underset{2015}{\text { SCORE }}$ & $\underset{2015}{\text { RANK }}$ & $\begin{array}{c}\text { RANK } \\
2014\end{array}$ & CHANGES \\
\hline Iran & & 856 & 1 & 1 & 0 \\
\hline Malaysia & & 803 & 2 & 2 & 0 \\
\hline Saudi Arabia & & 736 & 3 & 3 & 0 \\
\hline United & Arab & 380 & 4 & 6 & +2 \\
\hline $\begin{array}{l}\text { Emirates } \\
\text { Kuwait }\end{array}$ & & 267 & 5 & 5 & 0 \\
\hline Bahrain & & 263 & $\frac{3}{6}$ & 4 & -2 \\
\hline Indonesia & & 247 & 7 & 7 & 0 \\
\hline Qatar & & 209 & 8 & 10 & +2 \\
\hline
\end{tabular}

Source: Global Islamic Finance Report, 2015.

Table 3 Top 10 Fastest Growing Islamic Windows

\begin{tabular}{|c|c|c|c|c|}
\hline Rank & Institution & Country & $\begin{array}{c}\text { Sharia } \\
\text { compliant } \\
\text { assets } \$ \mathrm{~m}\end{array}$ & $\begin{array}{c}\% \\
\text { change }\end{array}$ \\
\hline 1 & Habib Bank Limited & Pakistan & $1.159,67$ & 127,31 \\
\hline 2 & $\begin{array}{l}\text { Export-Import Bank of } \\
\text { Malaysia }\end{array}$ & Malaysia & 781,14 & 52,88 \\
\hline 3 & Bank Muscal & Oman & $1.122,63$ & 43,01 \\
\hline 4 & National Commercial Bank & Saudi Arabia & $46.365,61$ & 38,92 \\
\hline 5 & Saudi Hollandi Bank & Saudi Arabia & $8.560,00$ & 31,99 \\
\hline
\end{tabular}

${ }^{6}$ Muhammad Abdul Mannan, (1980). The Objective of Islamic Banks, Dhaka, Bangladesh: Ins Thought of Islamic Banks, p.89.

${ }^{7}$ Agus Triyanta, "Implementasi Kepatuhan Syariah dalam Perbankan Islam (Syariah) (Studi Perbandingan antara Malaysia dan Indonesia)", Jurnal Hukum No. Edisi Khusus Vol. 16 Oktober 2009: p.209 - 228.

$8 \quad$ http://finance.detik.com/read/2015/06/13/160254/2941564/5/aset-keuangan-syariahmalaysia-terbesar-di-dunia-10-kali-lipat-dari-ri. accessed on April 28, 2016 at 08.37. 
AFEBI Islamic Finance and Economic Review (AIFER)

Vol.03 No.01, June 2018

\begin{tabular}{cllll}
\hline 6 & Saudi Invesment Bank & Saudi Arabia & $8.158,13$ & 31,55 \\
7 & Bank Pembangunan Malaysia & Malaysia & $2.105,15$ & 26,80 \\
8 & Samba Financial Group & Saudi Arabia & $18.393,87$ & 25,77 \\
9 & Arab National Bank & Saudi Arabia & $17.626,67$ & 25,19 \\
10 & RHB Capital & Malaysia & $10.347,61$ & 23,96 \\
\hline
\end{tabular}

Source: Maris Strategies \& The Banker, 2015.

In this case, Indonesia is very far behind with asset value of only US \$ 35.62 billion. The asset value in the neighboring country is 10 times that of the sharia finance industry in Indonesia. Yet the Muslim community in Indonesia is bigger. When viewed from the labor and office network of Islamic banking from 2010-2015 is increasing. In the sense that people's access to transactions in sharia banking is easier. This can be seen in the picture below: ${ }^{9}$

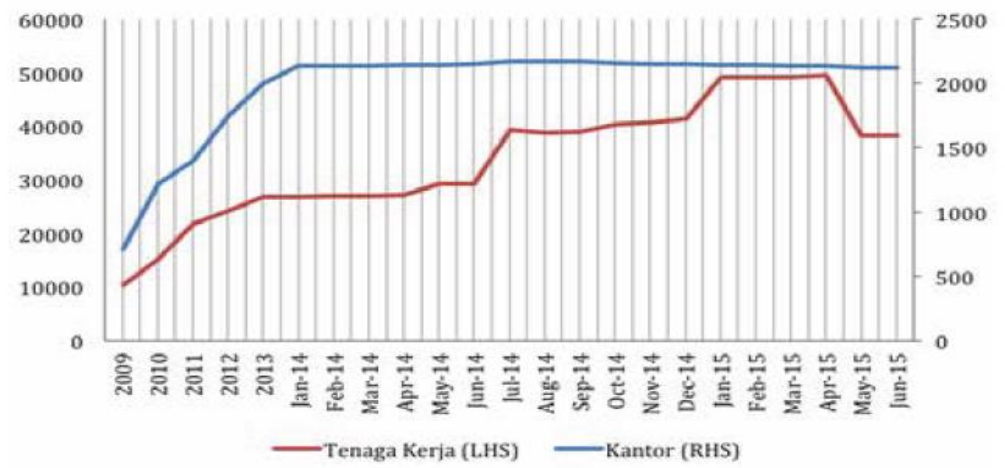

Figure 1 Labor and Network of Sharia Banking offices Source: statistics of Islamic banking, OJK.

But in fact that, along with the proliferation of sharia banking institutions in Indonesia over the last three years, the sharia banking sector has demonstrated a declining growth in assets, financing and third party funds. Several years earlier growth of these three indicators is quite good even reached 50 percent in 2011. But entering the year 2012, there is a decrease in the growth of the plot decreases. This is evident in picture 1 below:

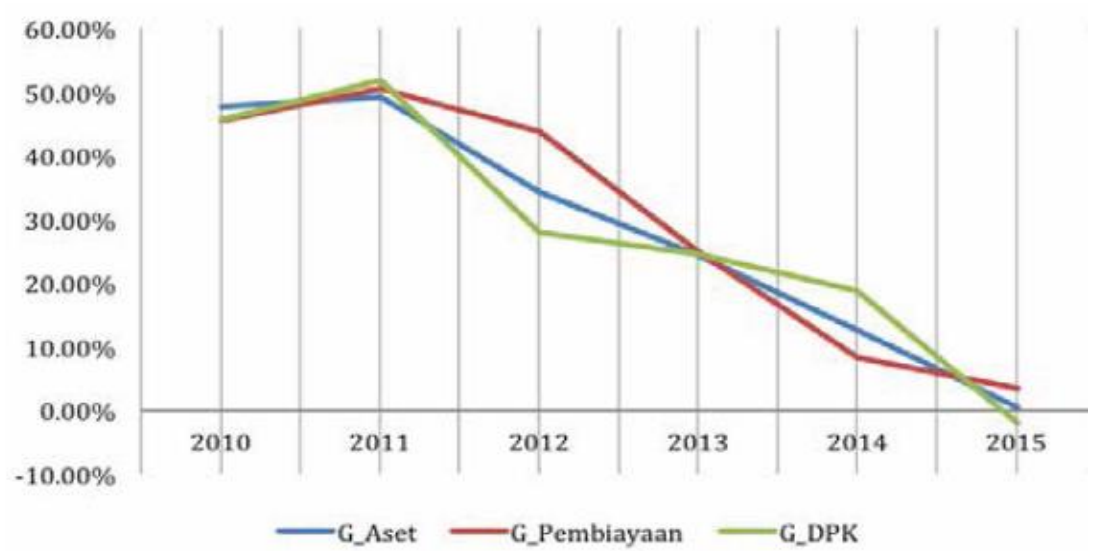

Figure 2 The growth of sharia banking 2010-2015

Source: Sharia Economic Outlook 2016 MES.

9 Sharia Economic Outlook, 2016 MES, p.05. 


\section{COMPARISON OF GOOD CORPORATE GOVERNANCE DISCLOSURE AND ACHIEVEMENT OF THE MAQASHID SHARIAH BETWEEN INDONESIAN AND MALAYSIAN ISLAMIC BANKS}

Therefore, this becomes academic anxiety at the practical level, could it be caused by the lack of GCG implementation and the achievement of sharia maqashid in sharia banks in that year?. So the researchers are interested in doing comparative analysis with Malaysian state which has the second rank in the world in shariah compliance.

\section{LITERATURE STUDY/HYPOTHESES DEVELOPMENT}

a. Good Corporate Governance

Bank Indonesia Regulation Number 11/33 / PBI / 2009 concerning Implementation of Good Corporate Governance for Sharia Commercial Banks and Sharia Business Units mentioned that good corporate governance (GCG), is a bank governance that applies the principles of transparency, accountability, responsibility, professionalism, and fairness. ${ }^{10}$ is a bank governance that applies the principles of transparency, accountability, by the Forum to Corporate Governance in Indonesia (FCGI) interpreted: "a set of rules governing relationships between shareholders, managers of companies, creditors, governments, employees and other internal and external stakeholders relating to their obligations and rights or in other words a system that controls the enterprise, where the objective of corporate governance is to create added value for all stakeholders. ${ }^{11}$

Implementation of GCG has been started by conventional banking, and started also implemented in sharia banking. Of course, the implementation of the two is different in both types of banking. One of them is from the philosophy of GCG implementation in sharia banking. This begins from the philosophy of the existence of Islamic banking, as the embodiment of Muslim ideals to achieve falah (prosperity) in the world and in the hereafter.

A business that is guided by spirituality and ethics will create a healthy and sustainable business climate with the realization of market discipline that is born from a good business governance culture. In order to realize the culture of governance in the business world, Rasulullah SAW is very concerned about the discipline in the implementation of business activities, both through direction and market inspection in the hope of the realization of business activities based on akhlaqul karimah so as to continue to provide benefit and expediency and avoid the harm. ${ }^{12}$

b. Maqasid Shariah

Mohammed et al have developed a performance evaluation for sharia banking based on the maqashid index which refers to the concept of Abu Zahrah's shariah maqashid. Maqashid index is divided into 3 variables namely Individual Education (Tahdzib al-Nafs), Establishing justice (Iqamah Al-Adl), and Maslahah (Welfare). Then, of the 3 variables are transformed into ten performance ratios. ${ }^{13}$

${ }^{10}$ Peraturan Bank Indonesia Nomor 11/ 33 /PBI/2009 about Pelaksanaan Good Corporate Governance Bagi Bank Umum Syariah and Unit Usaha Syariah section 1 paragraph 10.

11 Anis Wulandari, Menyingkap Nilai Keadilan (dalam Perspektif Syariah Islam) yang Terkandung Didalam GCG, Jurnal Investasi,Vol.6 No.2 Desember 2010, p.95-110.

${ }^{12}$ Ika Yunia Fauzia, Abdul Kadir, (2014), Prinsip Dasar Ekonomi Islam: Perspektif Maqashid al Syariah, Jakarta: Prenada Media, p. 283.

${ }^{13}$ Muhammad Al Ghifari Dkk, Analisis Kinerja Perbankan Syariah di Indonesia dan Malaysia Dengan Pendekatan Maqashid Indeks, Jurnal Ekonomi dan Perbankan Syariah Vol. 3. No.2, October 2015: p.47-66. 
In this case, Islamic bank is a Islamic business institution that has a goal to contribute to achieve Maqashid Shariah. In developing the performance measurement of achievement Maqashid Shariah adopted Abu Zaharah's theory of al-maqashid. According to Abu Zahrah, he said that the achievement of Maqashid Shariah can be seen in at least three dimensions: Tahdhib al-Fard (Individual Education), Iqamah al-'Adl (Creation of Justice) and Jalb alMasahah (Achievement of Public Interest). ${ }^{14}$

\section{RESEARCH METHODOLOGY}

The method used in this research is quantitative method by using comparative analysis. The analysis technique used is Mann-Whitney test. Measurement of Good Corporate Governance discussed in this research using indicator of good governance of sharia business (GGBS) while Maqashid syariah using measurement maqashid index.

\section{RESULTS}

1) Implementation of Good Corporate Governance

Table 4 Good Corporate Governance Test Results

\begin{tabular}{ll}
\hline & GCG \\
\hline Mann-whitney U & 31,500 \\
Wilcoxon W & 76,500 \\
Z & $-0,829$ \\
Asymp. Sig. (2-tailed) & 0,407 \\
Exact. Sig. (2*(1-tailed sig.)) & 0,436 \\
\hline
\end{tabular}

Source: Processed Results of SPSS Data

Results obtained from the above statistical data processing using mann whitney test, obtained sig value of 0,407 (0.407> 0.05). This shows that there is no difference between GCG implementation of Indonesian Islamic Bank and Malaysian Islamic bank.

Table 5 Application of GCG of Indonesian Islamic Banks and Malaysia 2012-2014

\begin{tabular}{llcc}
\hline Year & \multicolumn{1}{c}{ Indonesia Islamic Bank } & $\begin{array}{c}\text { number of } \\
\text { disclosures }\end{array}$ & Percent \\
& & 34 & $90,48 \%$ \\
2012 & BSM (Bank Syariah Mandiri) & 34 & $90,48 \%$ \\
& BMI (Bank Muamalat Indonesia) & 33 & $88,10 \%$ \\
\hline BNIS (Bank Negara Indonesia Syariah) & 33 & $90,48 \%$ \\
\hline 2013 & BSM (Bank Syariah Mandiri) & 34 & $90,48 \%$ \\
& BMI (Bank Muamalat Indonesia) & 34 & $88,10 \%$ \\
\hline \multirow{2}{2}{014} & BNIS (Bank Negara Indonesia Syariah) & 33 & $90,48 \%$ \\
& BSM (Bank Syariah Mandiri) & 34 & $90,48 \%$ \\
& BNIS (Bank Muamalat Indonesia) & 34 & $88,10 \%$ \\
& Average & 33 & $88,60 \%$ \\
\hline
\end{tabular}

Source: data processing Annual Report.

\footnotetext{
14 Jumansyah Dan Ade Wirman Syafei, Analisis Penerapan Good Governance Business Syariah Dan Pencapaian Maqashid Shariah Bank Syariah Di Indonesia,Jurnal Al-Azhar Indonesia Seri Pranata Sosial, Vol . 2, No. 1, Maret 2013,p.04.
} 
COMPARISON OF GOOD CORPORATE GOVERNANCE DISCLOSURE AND

ACHIEVEMENT OF THE MAQASHID SHARIAH BETWEEN INDONESIAN AND

MALAYSIAN ISLAMIC BANKS

\begin{tabular}{|c|c|c|c|}
\hline Year & Malaysian Islamic Bank & $\begin{array}{l}\text { number of } \\
\text { disclosures }\end{array}$ & Percent \\
\hline \multirow[t]{3}{*}{2012} & $\begin{array}{l}\text { BIMB (Bank } \text { Islamic } \text { Malaysia } \\
\text { Berhad) }\end{array}$ & 33 & $88,10 \%$ \\
\hline & RHB (RHB Islamic Bank Berhad) & 35 & $92,86 \%$ \\
\hline & AMB (AmBank Islamic Berhad) & 32 & $85,72 \%$ \\
\hline \multirow[t]{3}{*}{2013} & $\begin{array}{llll}\text { BIMB } & \text { (Bank } & \text { Islamic } & \text { Malaysia } \\
\text { Berhad) } & & \end{array}$ & 33 & $88,10 \%$ \\
\hline & RHB (RHB Islamic Bank Berhad) & 35 & $92,86 \%$ \\
\hline & AMB (AmBank Islamic Berhad) & 32 & $85,72 \%$ \\
\hline \multirow[t]{4}{*}{2014} & $\begin{array}{llll}\text { BIMB } & \text { (Bank } & \text { Islamic } & \text { Malaysia } \\
\text { Berhad) } & & & \\
\end{array}$ & 33 & $88,10 \%$ \\
\hline & RHB (RHB Islamic Bank Berhad) & 35 & $92,86 \%$ \\
\hline & AMB (AmBank Islamic Berhad) & 32 & $85,72 \%$ \\
\hline & Average & 33,3 & $88,25 \%$ \\
\hline
\end{tabular}

Source: data processing Annual Report.

Table 6 Average Comparison of GCG Disclosure Annual Report.

\begin{tabular}{ll}
\hline \multicolumn{1}{c}{ Islamic Banks } & Average Disclosure \\
\hline Indonesian Islamic Bank & 33,7 \\
Malaysian Islamic Bank & 33,3 \\
Total & 67 \\
Average & 33,5 \\
\hline \multicolumn{2}{c}{ Source: Processed Results of SPSS Data }
\end{tabular}

1. Structure and Work Mechanism of the Board of Commissioners

a. Name and status of the Board of Commissioners

The six Islamic banks that were subjected to research for the period 2012-2014, have disclosed the names and status of their respective board of commissioners. The researcher is of the opinion that the disclosure of the name and status of the board of commissioners in each annual report of sharia bank is one form of the implementation of good corporate governance that is transparency. Disclosure of the name and status of the board of commissioners aims to enable stakeholders to know who is the board of commissioners, whether from internal company or from external parties who have qualified to become a board of commissioners and have fulfilled the fit and proper test.

b. Decomposition of the Functions and Work Mechanism of the Board of Commissioners

All sharia banks that are subjected to research have disclosed the functions and working mechanism of the board of commissioners. For example, the board of commissioners is generally responsible for collecting and providing advice to the Board of Directors and ensuring the Company's GCG implementation at all levels and levels of the organization.

c. Number of Meetings and Attendance Meetings of Members of the Board of Commissioners

Almost all sharia banks that are subjected to research disclose the number of meetings conducted by the board of commissioners 
and the number of attendance of the members of the board of commissioners in the meeting. For example, Bank Syariah Mandiri discloses the number of meetings conducted by the Board of Commissioners for a period of 8 times, namely internal meetings of the Board of Commissioners while AMBank Islamic Berhad holds 12 meetings in 2014 disclosed in the annual financial statements of pages 46-47. But there is one sharia bank that only disclose the number of meetings without disclosing the attendance of the board of commissioners of Bank Islam Malaysia Berhad.

d. Mechanism and Self Assessment Criteria About Performance of Board of Commissioners Members

This disclosure becomes important, as a form of accountability of members of the board of commissioners to stakeholders for the trust that has been given by stakeholders to them.

e. Explanation Regarding Supporting Committees

All objects in this study have revealed the names and composition of the committees supporting the Board of Commissioners and so are the functions of each of the committees established in assisting the execution of the duties of the Board of Commissioners. The committees that assist the execution of the duties of the Board of Commissioners are the Audit Committee, Risk Monitoring Committee and Remuneration and Nomination Committee.

In relation to the progress of the organization and the demand for the company to form an effective committee, the Board of Commissioners at the Indonesian Mumalah Bank (BMI) shall establish 1 (one) additional Committee, the Corporate Governance Committee disclosed in the financial statements page 46.

2. Structure and Work Mechanism of DPS

With the disclosed name of DPS, stakeholders know who is the DPS that will ensure the operational kesalariahan and halal product and operational. Of course, all parties that have been assigned to be members of DPS have received recommendation from DSN MUI and have adequate competence.

In general, in the annual report of sharia banks, it is mentioned that DPS has conducted guidance, giving consultation, evaluating, supervising and ensuring that bank operational activities have complied with sharia principles which have been determined by the fatwa of DSN MUI and sharia of Islam.

3. Structure and Mechanism of the Board of Directors

a. Name and Position of each member of the Board of Directors

All sharia banks that become the object of research 2012-2014 have revealed the names and positions of each member of the Board of Directors. For example, Bank Muamalah Indonesia reveals the names and positions of each member of the Board of Directors on the financial statements page 14-15, further on Bank Islam Malaysia Berhad names and respective positions have been disclosed in the financial statements page 42.

b. Explanation Concerning the Work Mechanism of the Board of Directors 
The Board of Directors shall be the organ of the competent company and shall be fully responsible for the maintenance of the company for the benefit of the company in accordance with the intent and purpose of the company and to represent the company in accordance with the articles of association. Explanation of the working mechanism of the Board of Directors can be seen as including the mechanism of decision making and the mechanism of delegation of authority. Although there are some syariah banks that do not include the mechanism of delegation of authority such as BMI.

c. Number of Meetings and Attendance of Members of the Board of Directors in the Meeting

Almost all sharia banks disclose the number of meetings and number of attendance at the board of directors. As BSM discloses it in the financial statements page 200, whereas the Board of Directors has attended various meetings including 45 internal meetings of the Board of Directors, 12 times and joint meetings of the Board of Directors and Board of Commissioners. BMI and BNIS are disclosed in the financial statements of pages 65 and 250. As for BIMB is disclosed on page 43, while RHB Islamic Berhad is on page 20 of the GCG annual financial statements.

d. Mechanism and Performance Appraisal Criteria Members of the Board of Directors

All sharia banks disclose the mechanisms and criteria for the performance assessment of the members of the board of directors of 2012-2014. This disclosure is a form of accountability of members of the board of directors to stakeholders for the trust that has been given.

4. Other structures

a. Disclosure of Vision, Mission and Corporate Values

In general, all sharia banks, especially those used as research objects, have expressed their vision, mission and value of each company. This shows that every business operational move from a mission and value for the sake of realizing the company's vision. However, there are syariah banks that do not disclose the values of the company ie RHB Islamic Bank and AMBank Islamic berhad.

b. Disclosure of Majority Shareholders

As an element of corporate transparency, all sharia banks have disclosed the majority shareholders.

c. Policy and Remuneration of Board of Commissioners, Directors and DPS

Almost all sharia banks disclose the total remuneration for the board of commissioners, directors and DPS completely except in RHB Islamic Bank and AMBank Islamic Berhad which do not fully disclose the amount of remuneration.

d. Transactions with Conflict of Interest Parties

In 2013, Bank Mandiri Syariah revealed that there were 29 cases of permanent employees and 5 cases by non-permanent employees while in 2014 there were 22 cases of permanent employees and 3 cases by non-permanent employees. But this is not 
explained in detail. While BNIS discloses no conflict of interest involving Directors and Board of Commissioners either directly or indirectly disclosed in the financial statements page 189 .

e. Reporting on GCG Implementation in the Annual Report

All the sharia banks that are the object of research have revealed the reporting of GCG implementation. In the execution of duties and responsibilities supported by organizations and work tools such as work order, corporate governance guidelines (the set of basic management of the company, policy, and Standard Operating Procedures (SOP) as the implementation of GCG.

f. Obligation to Pay Zakah and Implementation of CSR

All sharia banks during 2012-2014 have disclosed the implementation of zakah and CSR payments in their respective annual reports. payment of zakat and CSR is one form of social awareness of Islamic banks to the surrounding environment. All sharia banks express it as a caring attitude that cares for the less fortunate and the environment, which is done with various forms of humanitarian and social activities as a form of social responsibility.

Based on statistical test results that GCG disclosure does not show significant differences. However, at the level of the Sharia Board, there are some differences. the sharia banking legal framework in both countries equally recognizes the existence of two levels of Sharia supervision. The first level is the Sharia Board in the banking institution, and the second is the Sharia Council at the national level.

In Malaysia, the first level is called the Shariah Committee (SC), and the second is called the Shari'ah Advisory Council (SAC). In Indonesia, the first level is named with the Dewan Pengawas Syariah (DPS) and the national level is named with the Dewan Syariah Nasional (DSN). ${ }^{15}$ Nevertheless, the SAC in Malaysia, under the Central Bank Act (CBA) 1958 of article 16B, is positioned under the Central Bank and has the authority to regulate issues related to Islamic banking. ${ }^{16}$ While the DSN in Indonesia, is part of the Indonesian Ulema Council (MUI), which is not a government agency but has the authority to issue fatwas related to the problems of Islamic banking. With the birth of Law No. 21 of 2008 on Sharia Banking, a Sharia Banking Committee was established, ${ }^{17}$ which became an institution that formulated a DSN fatwa into the PBI.

\footnotetext{
15 The term used in sharia banking in Indonesia is the Dewan Pengawas Syariah (DPS). This is very clearly mentioned in the General Definition of Law no. 21 of 2008 Concerning Sharia Banking as well as in the Bank Indonesia's two most important Regulations, namely, PBI no. 6/24 / PBI / 2004 Concerning Commercial Banks Conducting Business Based on Sharia Principles as amended by Bank Indonesia Regulation no. 7/35 / PBI / 2005, PBI No. 8/3 / PBI / 2006 Concerning Amendment of Conventional Commercial Bank Operations to Commercial Bank Conducting Business Based on Sharia Principles and Opening of Bank Offices Conducting Business Based on Sharia Principles by Conventional Commercial Banks. It should be emphasized that the presence of DPS in sharia banking in Indonesia is the most distinguishing aspect between sharia banks and conventional banks. Didin Hafidhuddin and Hendri Tanjung, Manajemen Syariah dalam Praktik, Jakarta, Gema Insani Press, 2003, p. 39.

16 Agus Triyanta, Implementasi Kepatuhan Syariah dalam Perbankan Islam (Syariah) (Studi Perbandingan antara Malaysia dan Indonesia), Jurnal Hukum No. Edisi Khusus Vol. 16 Oktober 2009: 209-228.

${ }^{17}$ Low No 21 Tahun 2008 about Perbankan Syariah, Pasal 26 ayat (4) and (5).
} 


\section{COMPARISON OF GOOD CORPORATE GOVERNANCE DISCLOSURE AND ACHIEVEMENT OF THE MAQASHID SHARIAH BETWEEN INDONESIAN AND \\ MALAYSIAN ISLAMIC BANKS}

Research also shows that Sharia council members in both countries have equal responsibility in ensuring or guarding Shariah compliance, both in product and operation of Islamic banking. To support Sharia Board members in carrying out their duties, both countries prepare the necessary rules, related to membership qualifications, duties and obligations, recognition of published fatwas, and their independence from various interventions. ${ }^{18}$ In both countries, the qualifications set forth are not much different.

The main qualification is that they have to master issues related to fiqh muamalah and knowledge or practice in the field of financial transactions. This qualification is in line with what is advised by experts in Islamic law. However, if they do not perform the task well (misconduct) it will be disqualified, the rules in Malaysia clearly mention the problem dismissal (expenditure) and membership termination. ${ }^{19}$ while there are no related rules (expenditures) and dismissals in Indonesia.

Indonesia and Malaysia use different rules in the dual positions of Sharia council members. members of the Shariah Committee (SC) in Malaysia can not be appointed or appointed as a member of a supervisor at another bank. Similarly members of the Shariah Advisory Council (SAC) also can not be appointed as members of sharia councils at any bank. ${ }^{20}$ Whereas in Indonesia, members of Shariah supervisors may serve double positions with similar positions in other banks and two non-bank syariah financial institutions, as well as members of DSN. the dual positions of a DPS can be more than in previous years according to Bank Indonesia. ${ }^{21}$ For example, Bank Muamalat Indonesia (BMI) and Bank Negara Indonesia Syariah (BNI Syariah) have the same DPS. ${ }^{22}$

However, different approaches in sharia advisory and supervisory models between the two countries have led to different consequences. Malaysia adopted an advisory model, where the sharia council is an advisory body, while Indonesia adopts a supervisory model, in which the Sharia council is a supervisory body. This has brought about different consequences, that the Sharia Supervisory Board in Indonesia of sharia banks offering sharia services is responsible for reporting Shariah compliance issues to the Central Bank. Based on the report, the central bank should conduct a makeshift investigation.

18 In Malaysia, in the Guidelines on Unprecedented Banking Schemes (SPTF) 1993, also, Guidelines on the Governance of Shariah Committee for the Islamic Financial Institutions (BNM / GPS1) 2004. In Indonesia, Bank Indonesia Governor Circular Letter no. 8/19 / DPBS. about: Guidelines for Sharia Supervision and Procedures for Supervisor Result Reporting for the Sharia Supervisory Board, look at Agus Triyanta, The Implementation Of Shariah Compliance In Islamic Banking; The Role Of The Of The Shariah Board (A Comparative Study Between Malaysia And Indonesia), Dissertation International Islamic University Malaysia, 2009.

${ }^{19}$ Guidelines on the Governance of Shariah Committee for the Islamic Financial Institutions (BNM/GPS1) 2004.

${ }^{20} \mathrm{BNM} / \mathrm{GPS} 1,19 . \mathrm{b}$. and CBA 1958, section 16B (6).

${ }^{21}$ PBI No. 7/35/PBI/2005, section of 26.

22 Dual Position DPS, K.H Ma'ruf Amin at PT Bank Muamalat Indonesia, PT Bank Negara Indonesia Syariah, PT Bank Mega Syariah, PT Asuransi Jiwa Bringin Life (Syariah Business Unit), and PT BNI Life Insurance (Sharia Business Unit), look at the BNIS financial report p.217. 
while in Malaysia, not by members of the Shari'ah Committee (SC) who must handle the issue but the Supervisory Department of the Central Bank. ${ }^{23}$

In addition to strengthening local banks and financial systems, Malaysia has launched a globalized Islamic banking business. This plan is in accordance with the initiative for the process of harmonizing fatwas with global standards. This has been supported by the pioneering presence of members of the Shari'a Advisory Council (SAC) from outside Malaysia. in contrast to Indonesia, which further strengthens its national foundations, including by establishing the Sharia Banking Committee, as an effort to bridge the DSN fatwa with the PBI. This shows a step further in resolving the conflict about the authority of DSN which is part of the MUI, a non-governmental institution. ${ }^{24}$

2) Achieving Maqashid Shariah

Table 7 Result Mann-Whitney for Achieving Maqashid Shariah

\begin{tabular}{ll}
\hline & Maqasid Index \\
Mann-whitney U & 16,000 \\
Wilcoxon W & 61,000 \\
Z & $-2,163$ \\
Asymp. Sig. (2-tailed) & 0,031 \\
Exact sig. (2*(1-tailed sig.)) & 0,031 \\
\hline
\end{tabular}

Source: SPSS Data Processed Results

Results obtained from the above statistical data processing, obtained sig value of 0.031 . Where the significant value is smaller than the level of significance $(0.031<0.05)$, This shows that there is a difference between the achievement of maqashid shariah in Islamic Banks in Indonesia and Islamic Bank in Malaysia.

Financial ratios of maqashid performance can be seen in the table below:

Table 8 First indicator of Banking Performance Maqashid shariah (Education)

\begin{tabular}{lccccc}
\hline BANK & RATIO & PI 2012 & PI 2013 & PI 2014 & Average \\
\hline BSM & Education & 0,004439 & 0,002682 & 0,001773 & 0,002964 \\
BMI & Education & 0,004518 & 0,005444 & 0,003646 & 0,013608 \\
BNIS & Education & 0,008901 & 0,006343 & 0,005662 & 0,020906 \\
BIMB & Education & 0,028472 & 0,063675 & 0,051909 & 0,048018 \\
RHB & Education & 0,006732 & 0,006999 & 0,006631 & 0,006787 \\
AMB & Education & 0,016013 & 0,014362 & 0,014733 & 0,015036 \\
\hline
\end{tabular}

Source: Processed data results Maqashid Index

From the above table it can be seen that Bank Islam Malaysia Berhad has the best average performance indicators of the first maqashid in providing educational assistance, conducting research and development, training and

${ }^{23}$ Agus Triyanta, The Implementation Of Shariah Compliance In Islamic Banking; The Role Of The Of The Shariah Board (A Comparative Study Between Malaysia And Indonesia), Dissertation International Islamic University Malaysia, 2009.

${ }^{24}$ Agus Triyanta, Implementasi Kepatuhan Syariah dalam Perbankan Islam (Syariah) (Studi Perbandingan antara Malaysia dan Indonesia), Jurnal Hukum No. Edisi Khusus Vol. 16 Oktober, p.224. 


\section{COMPARISON OF GOOD CORPORATE GOVERNANCE DISCLOSURE AND ACHIEVEMENT OF THE MAQASHID SHARIAH BETWEEN INDONESIAN AND MALAYSIAN ISLAMIC BANKS}

promoting sharia banks with an average indicator of 0.048018 or $4.8 \%$. The next best performance indicator is BNI Syariah with an average indicator of 0.020906 or $2 \%$. Followed by AmIslamic Bank and Bank Muamalat with an average indicator of $1.5 \%$ and $1.3 \%$. Furthermore, RHB is $0.6 \%$ and BSM is $0.2 \%$.

From the results of performance indicators of all sharia banks in Indonesia 2012-2014 the average performance indicators of all sharia banking above 1 percent except in RHB and BSM. This proves quantitatively, the achievement of the first shariah maqasid: education is in accordance with the expected. As a percentage of Malaysian sharia banks are superior to Indonesia in achieving maqashid shariah in the first aspect (education).

Table 9 The Second Indicator of Banking Performance Maqashid shariah (fairness)

\begin{tabular}{llccrc}
\hline BANK & RATIO & PI 2012 & PI 2013 & PI 2014 & Average \\
\hline BSM & Fairness & 0,186887 & 0,185036 & 0,184648 & 0,185524 \\
BMI & Fairness & 0,214710 & 0,221353 & 0,220445 & 0,218836 \\
BNIS & Fairness & 0,177302 & 0,176419 & 0,176924 & 0,176881 \\
BIMB & Fairness & 0,312957 & 0,276316 & 0,271862 & 0,287045 \\
RHB & Fairness & 0,263773 & 0,229283 & 0,160378 & 0,217811 \\
AMB & Fairness & 0,249664 & 0,325054 & 0,359082 & 0,311267 \\
\hline \multicolumn{7}{l}{ Source: Processed data results Maqashid Index } & &
\end{tabular}

The maximum performance value of the achievement of the second maqasid (fairness) in weighting is 41 percent, so that quantitatively the achievement of the second maqasid performance indicator is better than the performance of the first maqasid. The highest achievement was obtained by AmIslamic Bank in 2014 of 35.90 percent. While the lowest average performance indicator recorded by BNI Syariah with a value of 0.1768 or 17.68 percent. This is because BNI Syariah is one of the new Islamic banks in Indonesia compared to Bank Islam Malaysia Berhad and Bank Muamalat Indonesia. however, overall, both of the above performance are led by Malaysian sharia banks.

Table 10 The Third Indicator of Sharia Banking Performance Maqashid: Maslahat

\begin{tabular}{lccccl}
\hline BANK & RATIO & PI 2012 & PI 2013 & PI 2014 & \multicolumn{1}{c}{ Average } \\
\hline BSM & Maslahat & 0,061737 & 0,061850 & 0,066074 & 0,06322 \\
BMI & Maslahat & 0,070057 & 0,071522 & 0,083189 & 0,074923 \\
BNIS & Maslahat & 0,038501 & 0,044883 & 0,048837 & 0,044074 \\
BIMB & Maslahat & 0,177354 & 0,011786 & 0,090880 & 0,090334 \\
RHB & Maslahat & 0,000860 & 0,000844 & 0,000924 & 0,000876 \\
AMB & Maslahat & 0,001782 & 0,001624 & 0,001389 & 0,00160 \\
\hline \multicolumn{5}{c}{ Source: processed data results maqashid Index. }
\end{tabular}

Based on the above calculation results, the overall value of BIMB is the highest during 2012-2014 with a value of 9\%. followed by BMI and BSM with $7 \%$ and $6 \%$ respectively. Meanwhile, the lowest value is RHB Islamic only reach $0.08 \%$. 
This shows the development of sharia banking should pay attention to the ratios in the third maqashid. Profit must be increased so that the development of sharia banking can maximize profits for income redistribution. The increasing profit of sharia banks will certainly increase the paid zakat so that the function of zakat that is as wealth distribution can be implemented by sharia banking. Sharia banking products should also focus their activities on real sector investments so that the ongoing economy will not only revolve in the financial sector but also in sectors that have a direct impact on the economy of the small people.

Table 11 Performance of Maqashid Syariah Index

\begin{tabular}{lllllll}
\hline \multicolumn{1}{c}{ BANK } & \multicolumn{1}{c}{ MI 2012 } & \multicolumn{1}{c}{ MI 2013 } & MI 2014 & Average & & Rank \\
\hline BSM & 0,253062 & 0,24958 & 0,252496 & 0,251709 & 4 & \\
BMI & 0,289284 & 0,298320 & 0,307280 & 0,298295 & 3 & \\
BNIS & 0,224704 & 0,227644 & 0,231423 & 0,227924 & 5 & \\
BIMB & 0,518784 & 0,351777 & 0,414651 & 0,428404 & 1 & \\
RHB & 0,271365 & 0,237126 & 0,167932 & 0,225475 & 6 & \\
AMB & 0,267458 & 0,341039 & 0,375204 & 0,327900 & 2 & \\
\hline
\end{tabular}

Source: processed data.

Table 12 Comparison Of Maqashid Sharia On Indonesian Islamic Banks and Malaysian Islamic Bank.

\begin{tabular}{llll}
\hline $\begin{array}{c}\text { Indonesia } \\
\text { Islamic } \\
\text { Bank }\end{array}$ & Value & $\begin{array}{c}\text { Malaysian } \\
\text { Islamic Bank }\end{array}$ & Value \\
\hline BSM & 0,251709 & BIMB & 0,428404 \\
BMI & 0,298295 & RHB & 0,225475 \\
BNIS & 0,227924 & AMB & 0,327900 \\
Average & 0,259309 & & 0,327259 \\
\hline
\end{tabular}

Source: processed data.

From the table above can be seen that Bank Islam Malaysia Berhad became the highest sharia bank with average maqasid syariah index of 0.4284 or 42.84 percent and then AmIslamic Bank Berhad of 0.3272 or 32.72 percent, then Muamalat of 0.2982 or 29.82 percent, BSM 25.17 percent, BNI Syariah and RHB Islamic Berhad become syariah bank with the lowest maqasid performance that is 227924 or 22.79 percent and 225475 or 22.54 percent.

This result also shows that there are no Islamic banks that get high performance from maqashid index. The highest index is only 42.84 percent while the lowest value of 22.54 percent. but, the average Malaysian islamic bank has a better performance in achieving maqashid sharia than in Indonesia. This result has the same tendency with the results of Thuba Jazil and Syahruddin's research that found no sharia bank in Malaysia and Indonesia are able to recognize high performance in all 10 performance ratio of maqashid syariah, except on interest-free income ratio. ${ }^{25}$

There are several reasons behind the difference between the performance of maqashid sharia in Indonesia and Malaysia, including:

${ }^{25}$ Thuba Jazil And Syahruddin, The Perfomance Measures Of Selected Malaysian And Indonesian Islamic Banks Based On The Maqasid Al-Shari'ah Approach, Volume 7 Nomor 2, Sya'ban 1434/2013. 


\section{COMPARISON OF GOOD CORPORATE GOVERNANCE DISCLOSURE AND ACHIEVEMENT OF THE MAQASHID SHARIAH BETWEEN INDONESIAN AND MALAYSIAN ISLAMIC BANKS}

1. The Development of Islamic Banking in Both Countries

Historical analysis of the development of Islamic banking reveals that the two countries differ in that the political situation has significantly affected the growth of financial institutions in general, and Islamic banking institutions in particular. Strong political support in Malaysia has provided access to the rapid development of this institution, for example, with its excellent establishment process both in regulatory and management fields. ${ }^{26}$ Conversely, the lack of political support from the government during the early days of Islamic banking in Indonesia has resulted in slow progress for Islamic banking. ${ }^{27}$

The different political approaches to the economic development of the colonial period have made a difference to the different outcomes of the two countries. In this case, Malaysia is more benefited than Indonesia, it is evident from the establishment of a long-term plan of economic development of Malaysia by the colonial. ${ }^{28}$ This has resulted in a stable economic development, which in turn also facilitates the pioneering path for the development of Islamic banking in Malaysia. While in Indonesia, the Dutch government has exacerbated the country's economic development in the early stages by stopping the role of the Central Bank. Meanwhile, the new government of Indonesia is required to nationalize the Bank owned by the Netherlands to be then made the Central Bank. ${ }^{29}$

2. Implementation of Sharia Compliance

This study also reveals the differences in several aspects related to the implementation of Sharia compliance between Islamic banking business in Malaysia and in Indonesia. The Islamic banking in Malaysia has been supported by a strong legal instrument since its pioneering work, in Indonesia, the new law on sharia banking has only been published more than

${ }^{26}$ Before the establishment of Bank Islam Malaysia Berhad, as the first Islamic bank in Malaysia, the government has completed in a very fast time the related legislation, which came to be known as the Islamic Banking Act (IBA) 1983, in fact, the government also amends various other laws to smooth Islamic banking projects, which at least include amendments of Banking Act 1973 (section 2, section 9 and section 59), Amendment of Companies Act 1965 (section 4, section 218), Amendment of the Central Bank of Malaysia Ordinance 1958 (section 2, section 37, section41 and section 42) serta. Amendment of Finance Companies Act 1969 (section 2). Look at Islamic Banking Act (IBA) 1983, section 57-60.

${ }^{27}$ In regulatory aspects, amendments to the law for banking are made, is the issuance of Law no. 7 of 1992 on Banking, the beginning of the operation of BMI. In,Zainul Arifin, DasarDasar Manajemen Bank Syariah, Jakarta: Alfabet, 2005, p.5-6.

${ }^{28}$ British colonizers in Malaysia have provided a relatively well-established foundation for Malaysia's economic development. For example, Bank Negara Malaysia (BNM) was established during the colonial period, January 24, 1959 based on the Central Bank of Malaya Ordinance 1958. it is important to note also that the Malaysian economy itself has been designed by British colonials since 1930, In Agus Triyanta, The Implementation Of Shariah Compliance In Islamic Banking; The Role Of The Of The Shariah Board (A Comparative Study Between Malaysia And Indonesia), Dissertation International Islamic University Malaysia, 2009.

${ }^{29}$ The Dutch who had colonized Indonesia for about 3.5, did not recognize independence at the time of the proclamation of independence of Indonesia in 1945, in fact, the Dutch are still doing aggression to take control of the Republic of Indonesia. This situation concludes with the Round Table Conference, konferensi meja bundar (KMB) in 1949. One of its decisions is that Indonesia must stop the operation of the central bank which has been operating for about 3 years, namely Bank Negara Indonesia, and then have to nationalize the Dutch-owned bank, De Javasche Bank to serve as the central bank. 
15 years after sharia banking started operating in the country. In addition, to see the framework of sharia banking regulation in Indonesia is relatively complicated because it spread in various rules, from the Act, Bank Indonesia Regulation (PBI) and Circular Letter, which sometimes happens ambiguity in the setting (defining something). ${ }^{30}$

In issues related to fiqh, the two countries face different problems. The most notable issues in Malaysia are BayÑ al-Ênah, bay $\tilde{N}$ al-dayn and settlement of Islamic banking disputes. ${ }^{31}$ While the issues that appear in Indonesia is more elementary, is about usury on bank interest, affiliated madhhab in sharia banking development model, and so-called "conventional" contract on sharia banking. In terms of emerging issues, it appears that the two countries are in different stages of development. Malaysia is more on practical issues, while Indonsia is still philosophical and principle.

\section{DISCUSSION}

Malaysia and Indonesia are two Muslim countries in Southeast Asia, which, when examined, have many similarities. The two countries are dominated by the Malay population, adopting the Shafi'i madhhab in the majority and the strong adat influence in the legal system. So it is important to examine the financial business systems that occur in both countries.

A business that is guided by spirituality and ethics will create a healthy and sustainable business climate with the realization of market discipline that is born from a good business governance culture. The two countries adopt the rules of corporate governance by applying the principles of transparency, accountability, responsibility, professionalism, and fairness. Evident from the research results of both countries above, that in the disclosure of Good Corporate Governance in islamic banks of each country complements all items of good governance business sharia (GGBS) and does not show a significant difference.

Sharia council members in both countries have the same responsibility in ensuring or guarding Shariah compliance, both in the products and operations of Islamic banking. To support Sharia Board members in carrying out their duties, both countries prepare the necessary rules, related to membership qualifications, duties and obligations, recognition of published fatwas, and their independence from various interventions.

As a business institution, Sharia banks have a goal to contribute to achieve Maqashid Shariah. Indonesia and Malaysia have differences in achieving maqashid shariah. This is due to differences in the development of islamic banking and the difference in implementation of sharia compliance. The differences in political approach underlie the development of banks in both countries from colonial times until now. in the framework of islamic banking regulation, Malaysian Islamic bank has been supported with strong rule of law since its pioneering. while Indonesia's special law on sharia banking has been issued more than 15 years after sharia banking began operations.

\footnotetext{
${ }^{30}$ For example, the definition of "sharia financing" and "Principles of sharia" in Law No.10 of 1998 concerning Banking, section 1, paragraph 12 and section 2, paragraph 13.

${ }^{31}$ Agus Triyanta, Implementasi Kepatuhan Syariah..... p.222.
} 


\section{COMPARISON OF GOOD CORPORATE GOVERNANCE DISCLOSURE AND ACHIEVEMENT OF THE MAQASHID SHARIAH BETWEEN INDONESIAN AND \\ MALAYSIAN ISLAMIC BANKS}

In issues related to figh, the two countries face different problems. The most notable issues in Malaysia are BayÑ al-Ênah, bayÑ al-dayn and settlement of Islamic banking disputes. While the issues that appear in Indonesia is more elementary, is about usury on bank interest, affiliated madhhab in sharia banking development model, and so-called "conventional" contract on sharia banking. In terms of emerging issues, it appears that the two countries are in different stages of development. Malaysia is more on practical issues, while Indonsia is still philosophical and principle.

\section{CONCLUSION}

Based on the results of research and discussion, can be concluded that there is no significant difference between the disclosure of good corporate governance between Indonesian and Malaysian sharia banks. but have differences in the level of Sharia Board. as well as differences in the achievement of maqashid shariah.

\section{References}

Al Ghifari, M. et al. (2015). Analisis Kinerja Perbankan Syariah di Indonesia dan Malaysia Dengan Pendekatan Maqashid Indeks. Jurnal Ekonomi dan Perbankan Syariah. 3(2). .

Antonio, M. S. et al. (2012). An Analysis of Islamic Banking Performance: Maqashid Index Implementation in Indonesia and Jordania.Journal of Islamic Finance, 1(1), 012-029.

Arifin, Z. (2005). Dasar-Dasar Manajemen Bank Syariah. Jakarta: Alfabet.

Eagle, L. (2010). Exporting Islamic Banking From the Middle East. Banker's Academy Briefings. London.

Fauzia, I. Y., \& Kadir, A. (2014). Prinsip Dasar Ekonomi Islam: Perspektif Maqashid al Syariah. Jakarta: Prenada Media.

Guidelines on the Governance of Shariah Committee for the Islamic Financial Institutions (BNM/GPS1), 2004.

Hafidhuddin, D., \& Tanjung, H. (2003). Manajemen Syariah dalam Praktik. Jakarta: Gema Insani Press.

Jumansyah., \& Syafei, A. W. (2013). Analisis Penerapan Good Governance Business Syariah Dan Pencapaian Maqashid Shariah Bank Syariah Di Indonesia. Jurnal Al-Azhar Indonesia Seri Pranata Sosial, 2(1).

Komite Nasional Kebijakan Governance, (2001). Pedoman Good Corporate Governance. Jakarta. Indonesia.

Maksum. (2016). Perbandingan Debt Financing dan Equity Financing pada Perbankan Syariah di Indonesia dalam Pencapaian Tujuan Ekonomi Islam Perspektif Maqashid Syariah. Tesis Magister Studi Islam. 
Mannan, M. A. (1980). The Objective of Islamic Banks. Dhaka, Bangladesh: Ins Thought of Islamic Banks.

Mohammed, M. O., \& Razak, D. A. (2008). The Performance Measures of Islamic Banking Based on the Maqasid Framework. The IIUM International Accounting Conference (INTAC IV), 25 June.

Peraturan Bank Indonesia Nomor 11/ 33 /PBI/2009 Tentang Pelaksanaan Good Corporate Governance Bagi Bank Umum Syariah dan Unit Usaha Syariah pasal 1 ayat 10.

Sharia Economic Outlook 2016 MES.

Thuba Jazil And Syahruddin, (2013). The Perfomance Measures Of Selected Malaysian And Indonesian Islamic Banks Based On The Maqasid AlShari'ah Approach, Volume 7 Nomor 2.

Triyanta, A. (2009). The Implementation Of Shariah Compliance In Islamic Banking; The Role Of The Of The Shariah Board (A Comparative Study Between Malaysia And Indonesia). Dissertation International Islamic University Malaysia.

Triyanta, A. (2009). Implementasi Kepatuhan Syariah dalam Perbankan Islam (Syariah) (Studi Perbandingan antara Malaysia dan Indonesia). Jurnal Hukum No. Edisi Khusus, 16, 209-228.

UU No 21 Tahun 2008 tentang Perbankan Syariah, Pasal 26 ayat (4) dan (5).

World Islamic Banking Competitiveness Report 2013-2014.

Wulandari, A. (2010). Menyingkap Nilai Keadilan (dalam Perspektif Syariah Islam) yang Terkandung Didalam GCG. Jurnal Investasi, 6(2). 